323.1(498)(=161.2):392

Алехандру КІСЕЛЕВ,

Музей етнографії та художнього промислу/

Інститут еко-музейних досліджень (Тулча, Румунія)

Alexandru CHISELEV,

Ethnographic and Folk Art Museum

Institute of Eco-Museum Research from Tulcea (Romania)

(chiselevalexandru@yahoo.com)

orcid.org/0000-0003-1225-048

ResearcherID: R-1697-2017

УКРАЇНСЬКЕ НАСЕЛЕННЯ ТУЛЬЦЬКОГО ПОВІТУ РУМУНIÏ: МІЖ ТРАДИЦІЕЮ ТА ВИДОВИЩЕМ

\title{
UKRAINIAN COMMUNITIES FROM TULCEA COUNTY: BETWEEN TRADITION AND SPECTACLE
}

Кіселев Александру. Українські громади від повіту Тульча: між традицісю та видовищем. Мета дослідження. Представити ширшому читацькому колу елементи української нематеріальної спадщини з Добруджі та методи збереження цих предметів, особливо в народній драмі або подібних культурних проявах. У статті використано в якості методів дослідження спосіб усного, прямого та активного спостереження та співвіднесення 3 життєвими історіями живих свідків. Наукова новизна. Вперше досліджено елементи, що розглядалися як представники членів українських етнічних об'єднань, з порівняльної точки зору, у зіставленні їх 3 традиційними цінностями. Висновки. Аналізуючи різні аспекти нематеріальної спадщини, представлені на сцені або в інституційному контексті, можна класифікувати художні програми українських ансамблів 
Добруджан як справжніх, розроблених або стилізованих, 3 різними ступенями подання місцевої етнічної ідентичності.

Ключові слова: Добруджа, нематеріальна спадщина, хохол, етнічна ідентичність, виконавська майстерність.

\section{Chiselev Alexandru. Ukrainian communities from Tulcea County: between} tradition and spectacle. Aim of investigation. The article presents elements of the Ukrainian intangible heritage from Dobrudja and the methods of preserving these items, especially in spectacles or cultural manifestations. We used as research methodologies the oral methods, direct and participatory observation and the correlation with the life stories of the essential witnesses. Scientific novelty. For the first time, we researched the elements considered as representative by the members of the Ukrainian ethnic associations, from a comparative point of view with the traditional values. Conclusions. Analyzing different aspects of intangible heritage presented on stage or in an institutionalized context, we can categorize the artistic programs of the Dobrudjan Ukrainian ensembles as authentic, elaborated or stylized, with different degrees of presenting the local ethnic identity. Key words: Dobrudja, intangible heritage, Khokhol, ethnic identity, performing arts.

\section{Chiselev Alexandru. Les communautés ukrainiennes du comté de Tulcea} entre tradition et spectacle. L'objectif de l'article. L'article présente des éléments du patrimoine immatériel ukrainien de Dobroudja et les méthodes de conservation de ces objets, en particulier dans des spectacles ou des manifestations culturelles. Dans ce cas, nous avons opéré avec une distinction entre le contexte traditionnel et le contexte institutionnalisé, pour décoder différents ensembles de valeurs spécifiques. Nous avons utilisé les méthodologies de recherche suivantes: les méthodes orales (questionnaire, interview), l'observation directe et participative et la corrélation avec les histoires de vie des témoins essentiels pour la reconstitution orale de certains objets traditionnels. Le terrain de notre recherche a eu une double hypostase: la première, dans les villages, pour recueillir, 
reconstituer et restituer le patrimoine traditionnel et la seconde, sur la scène ou dans les festivals, pour observer et décoder les items utilisés comme représentatifs pour exprimer l'identité ethnique. Nouveauté scientifique. Pour la première fois dans les articles scientifiques de Dobroudja, nous avons étudié les éléments considérés comme représentatifs par les membres des associations ethniques ukrainiennes, d'un point de vue comparatif avec les valeurs traditionnelles pour accentuer les variations de construction de l'identité individuelle et collective.

Conclusions. En analysant les différents aspects du patrimoine immatériel présentés sur scène ou dans un contexte institutionnalisé, nous pouvons classer les programmes artistiques des ensembles ukrainiens de Dobroudja comme authentiques, élaborés ou stylisés, avec différents degrés de présentation de l'identité ethnique locale. Mots-clés: Dobroudja, patrimoine immatériel, Khokhol, identité ethnique, arts de la scène.

Topicality of the theme. In the last twenty years, but mostly in the last ten, certain elements of the immaterial heritage of populations from Dobrudja, in generally, and of Ukrainians / Khokhols from Tulcea County transformed, in relation with the social, politic-legislative and mentality changes.

Under the Law of protection of intangible cultural heritage No. 26/2008 ${ }^{1}$, intangible cultural heritage represents all the practices, representations, expressions, knowledge, skills - with the instruments, objects, artefacts and cultural spaces associated therewith - that communities, groups or individuals, recognize as part of their cultural heritage.

Contemporary ethnologists classify intangible heritage resources into five main categories: individual carriers of knowledge and know-how (so-called Living Human Treasures: artisans, musicians, folk medicines etc.), companies with potential knowledge and know-how (for example, professions such as baker, vintner, grocer), organisations-associations or informal groups (cultural

\footnotetext{
${ }^{1}$ LEGE nr. 26 din 29 februarie 2008, privind protejarea patrimoniului cultural imaterial, http://www.cimec.ro/Legislatie/Legea-26-2008-PatrimoniulImaterial.pdf .
} 
associations, folk ensembles), forms of expression (custom, feast or festival, ritual, playing and verbal forms) and cultural spaces (public places concentrating cultural traditional activities) ${ }^{2}$.

In a period of major changes in the socio-ethnic-demographic structure, many components of this type of heritage disappears or transforms. Some ways to preserve them, in an institutional framework, are: spectacle, festival or cultural manifestation.

We must make a distinction from the beginning between the traditional intangible heritage and the institutionalized heritage (and presented as part of the spectacles), in relation with necessity, role and significance.

\begin{tabular}{|c|c|c|}
\hline Coordinates & $\begin{array}{l}\text { Traditional intangible } \\
\text { heritage }\end{array}$ & $\begin{array}{l}\text { Institutionalized intangible } \\
\text { heritage (promoted by folk } \\
\text { ensembles) }\end{array}$ \\
\hline Temporal context & $\begin{array}{l}\text { inherently linked to calendar or } \\
\text { life cycle traditions } \\
\text { (synchronous) }\end{array}$ & $\begin{array}{l}\text { mainly related to festivals and } \\
\text { other cultural, educational, } \\
\text { social or political events } \\
\text { (sometimes synchronous, often } \\
\text { diachronic) }\end{array}$ \\
\hline $\begin{array}{l}\text { Character, depending on } \\
\text { organization }\end{array}$ & high spontaneity & organized, directed, managed \\
\hline $\begin{array}{l}\text { Character, according to the } \\
\text { significance of practices }\end{array}$ & ritualized & profane, spectacular \\
\hline $\begin{array}{l}\text { Character, according to the } \\
\text { transmitted value }\end{array}$ & authentic, with local variants & $\begin{array}{l}\text { standardized, } \\
\text { generalizing }\end{array}$ \\
\hline Direction of addressing & to community & to public \\
\hline $\begin{array}{l}\text { The understanding way of } \\
\text { phenomena }\end{array}$ & complex, decoded, interpretable & $\begin{array}{l}\text { simplified, for a general } \\
\text { understanding of public }\end{array}$ \\
\hline $\begin{array}{l}\text { Necessity of presenting the } \\
\text { practice }\end{array}$ & Sufficient by itself & $\begin{array}{l}\text { Sufficient, but with emphatic } \\
\text { trends, exaggeration or } \\
\text { replacement of items meant to } \\
\text { impress the public }\end{array}$ \\
\hline
\end{tabular}

Table No. 1 Differences between traditional and institutionalized intangible heritage

\footnotetext{
${ }^{2}$ Inventaire des ressources ethnologiques du patrimoine immatériel (IREPI).
} 
Thus, the two types of intangible heritage operate with different sets of values, according to the "target" of them. Traditional intangible heritage is created and centered on individuals and communities, and the institutionalized one is transformed / adapted / created by institutions and centered to the public, even if their intention is for preservation or awareness.

Given the complexity of intangible heritage, in this approach we will address some issues from a comparative perspective between traditional and spectacular.

Analysis of the last research. The intangible heritage of Ukrainians from Dobrudja was researched in the last decade by different ethnologists from Romania and Ukraine, such as: S. Pârâu, M. Milian, I. Titov, V. Kușnir, A. Chiselev ${ }^{3}$. They presented historical aspects of this community, traditional items (S. Pârâu, M. Milian, I. Titov, V. Kuşnir), study cases about localities where Ukrainians life in relation with other ethnic groups (I. Titov), folkloric texts, rites of passage, holidays, ethnoiatric medicine, material culture (V. Kuşnir), magical thinking, ethno-mythological representations, magical rites connected with life-cycle and calendar traditions (A. Chiselev).

These contributions are essential for knowing the traditional ethnographic values of Ukrainian minority of Dobrudja and represent the base of the future research to understand and accentuate the evolution of ethnicity in the last years.

Aim of the research. Using the bibliograhical data and oral methods in the field, the aim of this article is to present elements of the Ukrainian intangible heritage from Dobrudja and the methods of preserving these items, especially in spectacles or cultural manifestations. In this case we operated with a distinction

\footnotetext{
${ }^{3}$ Pârâu S., Multiculturalitatea în Dobrogea [Multiculturality in Dobrudja], Ed. Ex Ponto, Constanţa, 2007; Milian M., "Dobrogea ca mozaic etnic" [Dobrudja as ethnic mosaic], in Pârâu S., Multiculturalitatea în Dobrogea [Multiculturality in Dobrudja], Ed. Ex Ponto, Constanţa, 2007; Titov I. Relaţia majoritariminoritari etnici în Dobrogea de Nord [The relationship of ethnic majority-minority in Northern Dobrudja], Constanța, Ed. Dobrogea, 2015; Kuşnir V., Ucrainenii de dincolo de Dunăre [Ukrainians beyond the Danube], RCR Editorial, București, 2008; Chiselev A. Magia la românii și ucrainenii din nordul Dobrogei [The magic at the Romanians and Ukrainians from the Northern Dobrudja], ClujNapoca, Ed. Mega, 2016.
} 
between the traditional context and the institutionalized one, to decode different sets of specific values.

The field of our research had a double hypostasis: the first one, in the villages, for collecting, reconstitute and restitute the traditional heritage and the second one, on the stage or in festivals, to observe and decode the items used as representative to express the ethnic identity.

Report of the main material. Context of identity manifestations. In the post-communist period, democratization of thinking in terms of ethnic freedom, coupled with the ratification of conventions to protect the rights of minorities and the emergence of institutions or organizations of ethnic representation, determined an effervescence of ethnicity expression at central and local level.

In this context was founded the Union of Ukrainians from Romania $(\mathrm{UUR})^{4}$, as organisation with ethnic profile, non- governmental and nonprofit, with legal personality acquired under the Law No. 246/2005. The subsidiary from Tulcea County belongs to this organization and has in charge various local organizations.

Another Ukrainian ethnic organisation is the National Forum of Ukrainians from Romania (NFUR), founded in June 2009.

In the subsidiary from Tulcea County operate several local groups or ensembles that transmit the Ukrainian heritage: Music and dance ensemble Zadunaiska Sici / Danubian Sich from Tulcea, choral group Veselka / Rainbow from Caraorman, choral group Rebalka / Fisherman from Crișan, choral group Dunai / Danube from Pardina, choral group Ceorne More / Black Sea from Sfântu Gheorghe, choral group Bila Roja / White Rose from Letea, choral group Bila Makovka / White Water Lily from Chilia, choral group Zirocika from Ciucurova etc.

There are clear differences between these folk ensembles, in terms of clothing, promoted stage repertoire or attitude. From this perspective, the ensemble

\footnotetext{
${ }^{4}$ UUR was established in 28.12.1989, and on 14.02 .1990 , was granted with juridical personality by the District I Court from Bucharest.
} 
from Tulcea is the most innovative and transmits minor North-Dobrogea specific, transforming the Ukrainian heritage in a product promoted through ethnic marketing strategy. Without fail, we can say that this ensemble is promoter of Ukrainian identity, in general, rather than the identity of Ukrainians / Khokhols from Dobrudja.

This was due to cultural exchanges with Ukraine, the existence of media communication channels, powerful sources of information and inspiration and material resources.

Memory and identity. The main localities from Tulcea County where Ukrainians (Zaporozhian Cossacks and peasant farmers) sat, over time, are: Dunavăţu de Jos, Dunavăţu de Sus, Sfântu Gheorghe, Murighiol, Prislav (Nufăru), Pârlita (Victoria), Caraorman, Ciucurova, Teliţa, Tulcea Veche, Azaclău (I. C. Brătianu), Letea, Chilia Veche, Pardina, Pătlăgeanca, Uzlina, Ceatalchioi, Murighiol, Frecăței, Țiganca (Nifon), Geaferca Rusă (Căprioara), Hamcearca. Many settled latter in Tulcea and some villages were depopulated ${ }^{5}$.

One of the ethnonyms used to denominate the Ukrainians from Dobrudja is Hahol (plural Haholi / Hahli). The original meaning of the term is lost, none of the interviewed informants not knowing what it represents ${ }^{6}$. The only known element is that Hahol language differs to some extent with the Ukrainian language, being perceived by them as a dialect.

It seems that the term was originally used as an insult of Russians to Ukrainians, khokhol designating the well known style of haircut of Zaporozhian Cossacks.

In fact, the Cossack haircut is a standard element in expressing the stereotyped image of the Cossack. Later, after the creation of the U.U.R. Tulcea, as an institutionalized form of promoting Ukrainian culture, the origins of the Zaporian Cossack are brought to the forefront, inclusively on the stage (Cossack

\footnotetext{
${ }^{5}$ Milian M., "Dobrogea ca mozaic etnic" [Dobrudja as ethnic mosaic], in Pârâu S., Multiculturalitatea în Dobrogea [Multiculturality in Dobrudja], Ed. Ex Ponto, Constanţa, 2007, pp. 187-198

${ }^{6}$ Interviewed person: Eugenia Crimski (born in 1943, Letea): I don't know (what Khokhol means) ... so people say, so we say...
} 
costume, songs in which the image of the Cossack is omnipresent, the dance "kazacioc" etc.)

Catriona Kelly analyzes the apellatives attributed to the Others in Russian culture, identifying certain denigrating names, including khokhol, meaning dirty Ukrainian. $^{7}$

In Dobrudja, this term was used to differentiate even at ethnonymic level, Ukrainians (Little-Russians, Russki) and Russians-Lippovans, who used it with the meaning "unclean, dirty" (pagan or with other faith). Over time it has lost, by usage, any negative substrate and became ethnonym.

In the Ukrainian communities from Dobrudja, certain ethnonymes of secondary rank are used to represent the Other, in this context the khokhol from other villages. In most cases, the occupational profile is used as a differentiating factor.

The Ukrainian inhabitants from Caraorman village are nicknamed cabaché (pumpkins), those from Sfântu Gheorghe - cheşmané (guts of sturgeon), those from Letea - baclajane (tomatoes), those from Pardina - baranciki (ram breeders), those from Ceatalchioi - cheșleaché (derivation from cheșleac - sour milk) ${ }^{8}$.

Although the linguistic perspective, Ukrainians from Tulcea County spoke and speak Ukrainian steppe idioms ${ }^{9}$, but at cultural events is promoted primarily literary Ukrainian language and, just at secondary level, the local specificity of expression forms (e.g. differences between New Year carols / scidrivki ${ }^{10}$ from various villages of the delta).

\footnotetext{
${ }^{7}$ Kelly C., The Cambridge Companion to Modern Russian Culture, Cambridge University Press, 1998, P. 152.

${ }^{8}$ Interviewed persons: Mihaela Holostencu (born in 1993, Tulcea), Ana Chiselev (born in 1926, Letea), Liliana Fediuc (born in 1963, Chilia Veche), Maria Bălan (born in 1944, Sfântu Gheorghe), recorded by Alexandru Chiselev (2017).

${ }^{9}$ Steppe idioms must be considered as transition idioms from South-Eastern to South-Western idioms, based on the South-Eastern dialect features.

${ }^{10}$ In Letea village, three of these are still preserved even today: A uciora iz vecera, Pasla Melanca dva caciura (Yesterday in the evening, Melanca grazed two ducks), Jidivskaia krovi (Jewish Blood) and Hodela Melanca (Melanka went - the shorter version, for kids).
} 
We consider prioritized the preservation (documenting, recording and promoting) of these linguistic and stylistic variations, since the population who speaks Ukrainian actively is aging, and the young one uses it as secondary or tertiary language or don't use it anymore.

Variations of building individual and group identity. In relation with the strategy of building the identity (personal or collective; contextual), there are several situations to approach the ethnicity, such as:

- Ukrainians, generally elderly who accept and self-identify using the ethnonym haholi - e.g. Letea, Caraorman, Sfântu Gheorghe, Dunavățu de Jos (in the past compact ethnic settlements). They present, in terms of emotional perspective, stronger links with the native Ukrainian ethnos, causing conservation of many traditional elements.

- Ukrainians, generally young people, who reject the ethnonym haholi. (e.g. in Ceatalchioi). In this case we observed the preservation of some traditional elements generated by the spatial context and ethnicity.

- Ukrainians, generally young people, who have accepted the Romanian identity and declare themselves Romanians (e.g. in Partizani, Tulcea). In this case the phenomenon of acculturation is almost total.

- Ukrainians who accepted another identity (e.g. by mixed marriages) and practice it (however, the Ukrainian ethnicity is latent). In this case appears the phenomenon of acculturation.

- Romanian, generally young, or other ethnic supporters who approach the Ukrainian identity as members of the Ukrainian assemblies.

Some aspects of Ukrainian heritage. Costume represents an identity mark of a population. We consider necessary to analyze it, because it has a major visual impact to the public, when the ensemble performs on stage. Following the appearance of opportunities to expose the Ukrainian ethnicity in festivals with ethnic profile (music, dance, gastronomy etc.), it was necessary the reconstitution of a costume for scenic representation. 
It is difficult to reconstitute the traditional costume of Ukrainians who established in different period in Dobrudja area. Periods of war, poverty and famine, continue oscillations to find the establishment place, influences of urban areas (Tulcea, Sulina, Vâlcov) led to the disappearance and / or transformation of woven pieces. The collective memory retains some data, especially from the early twentieth century, those confessed about clothing with urban influences (industrial materials) ${ }^{11}$.

Analyzing the bibliographic data ${ }^{12}$ and adding the field information ${ }^{13}$, we can conclude that the morphological structure of women's clothing, from the late nineteenth century and the first part of the twentieth century, included: head-dress (kosenka, platoc, berda ${ }^{14}$ ) ; blouse (cohta); skirt (spidneţea - one above; yupka - a kind of underskirt, made of white textile, with lace); dress (platia), originally homespun from wool ${ }^{15}$, after that from industrial materials ${ }^{16}$; apron (fartuh); vest (jiletka); coat with bellbottom tailoring (caţaveica); shoes: socks woven from wool (ciulchi), sandals (postolé) from pigskin or beef, replaced with boots.

Men's clothing morphological structure included: fur cap, hat (capiliuha); shirt (sorocika ${ }^{17}$ ); belt (poias); pants (ștané); vest, over shirt, equipped with buckle for adjustment (jiletka); coat for cold weather (caparan); shoes. We note that pants were made of wool woven in four threads and thereafter of fabric. Elders wore shirts with detachable cuffs (ciohli) and collar, attached to it by a system of clasps.

Shoes were made of leather from beef, sheep or dog (considered the best). The sole, made from thicker leather, was sewn with hard thread (dradva) and fixed well using wooden cloves. On the heel and on the toes are put one little horseshoe,

\footnotetext{
${ }^{11}$ Pârâu S., Multiculturalitatea în Dobrogea [Multiculturality in Dobruja], Ed. Ex Ponto, Constanţa, 2007, P. 118.

${ }^{12}$ Kuşnir V., Ucrainenii de dincolo de Dunăre [Ukrainians beyond the Danube], RCR Editorial, Bucureşti, 2008, P. 230; Arbore Al. P., "Sicia transdunăreană după Th. Condratovici" [Transdanubian Sich after Th. Condratovici], Analele Dobrogei, Revista Societății Culturale Dobrogene [Annals of Dobruja, Journal of the Dobrujan Cultural Society], 1935, An XVI, Cernăuți, P. 72.

${ }^{13}$ Interviewed person: Ana Chiselev (born in 1926, Letea), recorded by Alexandru Chiselev (2011).

${ }^{14}$ Depending on the age and economic or civil status, women wore: platoc (white, cream, brown, black), berda, shawl, expensive and rare (only older women).

${ }^{15}$ Wool-warp and weft, dyed with oak bark

${ }^{16}$ Were used materials such as vender (nailon), poplin, flowered textiles.

${ }^{17}$ The name is found in a version of the carol for Melanka tradition.
} 
to not erode the sole. These shoes were worn at holidays, at dances. At work they wore sandals (postolé). The wealthy and married wore long boots like those worn by officers, made in leather, with buckles.

Currently, in the Ukrainian assemblies from Tulcea County, exist different variants of stage costume.

The most diverse costume is presented by the members from ensemble Zadunaiska Sici, showing several periods of Ukraine's culture (Cossack, Kievan).

The girls who dance wear a costume from Kiev region, with vinok (crown of flowers and ribbons) on the head, shirt with floral patterns in cross stitched point, plakhta (a piece with the role of a skirt made of three components like the apron) and flowery apron, kersetka (long jacket flared on back), red boots.

Men's costume, worn during dances reminds of that used by the Cossacks, and is composed by: zupan (a long coat worn over the shirt), shirt with tunic-type collar, partially buttoned with three buttons, sharovary (large pants), wide belt, red boots.

Married women from the choir of ensemble Zadunaiska Sici wear a costume similar to that of women from assemblies from Crișan, Pardina and Caraorman: shirt, vest and floral skirt. The only group who still use the head-dress (kosenka) as mark of wife is Bila Roja from Letea.

Representative alimentation vs. Presented alimentation. Distinct elements of traditional Ukrainian alimentation can be found in some gastronomical preferences generated by the occupational profile, and especially in the gestures and beliefs during the preparation of ceremonial dishes. Is the case of wedding dough (şeşca, lejâi) in the preparation of which take account of certain habits (any piece of dough must not remain unused, because the couple will soon separate; were interpreted certain ritual songs about the transition from girl to married women category etc.).

Some of the customary products are the bread made in the clay oven and simple bakings with various fillings (blinţi - flat cakes made before the fire, from 
bread dough less consistent; piroghi or piroşké - baked or fried pies; pumpkin, cabbage, potatoes ${ }^{18}$ pies).

Basic food consisted of polenta and milk (raw, cooked, corasla ${ }^{19}$, in various food products) and dairy products, fish (fried, boiled, roasted, fish soup) and cabac / pumpkin (slices baked in oven, fried cabac, cabac boiled with milk), cabbage (in soups, in holubţî, capusniak - cabbage with rice or potatoes, with fried onion) etc. From chopped meat were made touceniché (meatballs) or holubţî (stuffed cabbage rolls).

Complementary, were used aliments from nature: water caltrop, cattail root, water lily seeds, berries, wader birds (coots, geese), venison etc.

For winter they put pickles in brine (chopped cabbage in barrels of 3 buckets, others pickles mixed together, in barrels). The fruits were dried in the oven, then when was needed or in the Christmas Eve was made osvar ${ }^{20}$ (compote of prunes, apples, and quinces). It was made quince or grapes jam, and instead of sugar was used sugar beet ${ }^{21}$. They say what it's not Christmas without nuts. These were baked in shell in the oven. The core was like the breadcrumbs, sprinkled with salt.

For Vecera ritual meal in the Christmas Eve (January 6), in the past, were prepared twelve dishes, three of them being essential: osvar (compote with dried fruit), kukea (boiled wheat mixed with honey and nuts) and piroghi ${ }^{22}$.

Today, in festivals or gastronomic competitions, organized by various associations and NGOs, are presented stereotypically products as identity marks, although their ethno-cultural appurtenance is much larger and here is used the idea of Delta's brand (e.g. roasted carp, fish soup, stuffed pike). Instead, ritual foods, used in the holiday calendar and cycle life events (kukea, osvar, pampușka, hrestec

\footnotetext{
${ }^{18}$ Chopped potatoes, with a little bit of onion fried in oil and salt, were put into a bundle of dough, then these pies are baked on the fireplace.

${ }^{19}$ It is used first, second and third milk after the cow calves, with many egg and sugar.

${ }^{20}$ This is one of the twelve gastronomic products for the Vecera dinner.

${ }^{21}$ It was washed, cleaned, boiled, squeezed and used for sweetening the products (jams, biscuits).

22 Titov I. Relația majoritari-minoritari etnici în Dobrogea de Nord [The relationship of ethnic majorityminority in Northern Dobrudja], Constanța, Ed. Dobrogea, 2015, P. 161.
} 
/ caleadnec, șeșke, korovai, lejâi) are only rarely presented (only in some community events).

Repertoire of calendar and family ritual texts. From the current state of research, we can conclude that still can be collected from the field a rich poetic repertoire of Christmas carols (coleadi ${ }^{23}$ ) and New Year songs (scidrivki) or texts with matrimonial value (wedding songs - vesilni pisni ${ }^{24}$ ).

A tradition with carnival elements usually take place on the evening of January 13, when people went with Melanka. With this occasion, the group of singers performed different scidrivki (New Year carols).

In the suite of Melanca were these characters, which entered in the house: Melanka (travesty), cozac/Cossak (the lad, the soldier with the sword), gipsy ${ }^{25}$. The group of 15 to 20 singers remained outside the house. Melanca was dressed in white dress, like a bride, with a scarf / platoc on the head. There was a coordination between the inside performance (arranging the bed, sweeping and shaking the mat, washing dishes by Melanka) with the lyrics sung by singer's group outside. $^{26}$

We present, in Latin script, the short variant of Melanka, for children: Hodela Melanka / Vaselcu prosela / Vaselcu naş batiu / Puste nas u hate / Bo me jeto jale / Zolotei hrest dirjale / Zolotu cadelneţcu / Caditesea liude / Bo u vas Hristos bude / Zasteialte stole / Zamitaite dvore / A nam calachi daite. ${ }^{27}$

\footnotetext{
${ }^{23}$ Coleadi were sung as a polyphonic composition. Among these we remember about the religiously inspired carols (in fact they tell in a rhymed and versified mode about biblical events): Oi Temnoi (You, the Dark one), Na Siancăi Hore (On the Sinai Mount).

${ }^{24}$ Many of these are a type of dialogue in various moments of the wedding: when the bride chose her druşchi, at holoveţea (party in the Saturday before wedding), when the wedding group was received by the bride's mother at the door ( $\mathrm{Na}$ dviri, Oi dvoricu); when the mother washed the groom's head (Saturday night), when the bride was dressed, when people danced with the bridal textile (sovon); after the wedding, when the bride arrived at the groom's house and mother bough them inside the house with a towel (Ne upiznala matii), when the head of the bride was covered (married women sung on this time).

${ }^{25}$ Interviewed person: Ştefan Savencu (born in 1921, Caraorman), recorded by Alexandru Chiselev (2011).

${ }^{26}$ Chiselev A. Magia la românii și ucrainenii din nordul Dobrogei [The magic at the Romanians and Ukrainians from the Northern Dobrudja], Cluj-Napoca, Ed. Mega, 2016, P. 137.

${ }^{27}$ Went Melanka / And asked Sf. Basil / Basil, our father / To let us inside your house / Because we reaped with the sickle / Gold Cross we held / And golden censer / So the world enjoy / Because Christ comes to you / Prepare the tables / Sweep the courts / And give us round breads.
} 
Although the field repertoire is still rich, it is poorly highlighted in terms of stage representation (especially wedding songs and traditional dances - e.g. Zaicec / Bunny, Păpurişca / Little Cattail). Sometimes it is presented in a contrary manner to the traditional standards.

A special situation occurs when certain events involving music and dance are held during Lent, which is contrary to their religious beliefs. In these cases, members of assemblies pass over these traditional rules, using musical instruments as accompaniment. As resistance to this modern fact, we noticed that during the Anniversary Festival of Ukrainian tradition "200 years from the birth of Taras Shevchenko", held on March 30th 2014, the vocal group of Letea performed $a$ capella sober songs.

Instead of conclusions... Considering these aspects mentioned above, guided by $\mathrm{CIOFF}^{28}$ definitions about the programs on the stage, we can categorize the artistic programs presented at various festivals by Dobrudjan Ukrainian ensembles, as follows:

- authentic program - determined by a local or regional mark, traditional costumes or faithfully reconstituted, performing music and dance without arrangement.

- elaborated program - generated by a content who cover a number of regions, adapted costume, harmonized music and modified dances, the creation of new dances that uses the traditional and authentic elements.

- stylized program - generated by a content inspired from traditional culture, recreated costume for the needs of the stage, musical and choreographic elements adapted and recreated to meet the needs of modern stage.

Alexandru Chiselev - curator at Ethnographic and Folk Art Museum from Tulcea (Romania); PhD student in Cultural Studies at University of Bucharest with

\footnotetext{
${ }^{28}$ International Council of Organizations of Folklore Festivals and Folk Arts.
} 
the theme "Ritual dynamics of calendar traditions"; author of the volume Magia la românii și ucrainenii din nordul Dobrogei [Magic at Romanians and Ukrainians from Northern Dobrudja]; Research interests: magical thinking, immaterial heritage of the ethnic or ethno-confessional groups from Dobrudja (Romanians, Aromanians, Meglenoromanians, Ukrainians, Russian-Lippovans, Bulgarians, Greeks, Turks, Tatars, Italians, Germans, Rroma, Muslim Rroma, Gagauzians, Molokans, Skoptsy etc.).

Олександру Кіселев - куратор в Етнографічному та народному художньому музеї Тулча (Румунія); Аспірант кафедри культурології Бухарестського університету 3 темою "Ритуальна динаміка календарних традицій"; автор праці «Magia la românii şi ucrainenii din nordul Dobrogei» [магія у румунів та українців з північної Добруджі]; Наукові інтереси: магічне мислення, нематеріальна спадщина етнічних або етноконфесійних груп з Добруджі (румуни, аромани, мегленорумани, українці, росіяниліпповани, болгари, греки, турки, татари, італійці, німці, рома, мусульманська рома, гагаузійці, Молокани, скопці тощо).

Photo 1 - Zadunaiska Sici Ensemble from Tulcea, 2014, author photo

Photo 2 - Dunai Choral Group from Pardina, 2014, author photo

Photo 3 - Bila Roja Choral Group from Letea, 2014, author photo

Photo 4 - Șeșka molodoi - wedding ritual bread, 2013, photographer:

Iuliana Titov

Photo 5 - Lejăi - wedding ritual bread (Letea, 2010), author photo. 